\title{
Evolution of nectarivory in phyllostomid bats (Phyllostomidae Gray, 1825, Chiroptera: Mammalia)
}

\author{
Thomas Datzmann*1,2,3, Otto von Helversen² and Frieder Mayer1,2
}

\begin{abstract}
Background: Bats of the family Phyllostomidae show a unique diversity in feeding specializations. This taxon includes species that are highly specialized on insects, blood, small vertebrates, fruits or nectar, and pollen. Feeding specialization is accompanied by morphological, physiological and behavioural adaptations. Several attempts were made to resolve the phylogenetic relationships within this family in order to reconstruct the evolutionary transitions accompanied by nutritional specialization. Nevertheless, the evolution of nectarivory remained equivocal.

Results: Phylogenetic reconstructions, based on a concatenated nuclear-and mitochondrial data set, revealed a paraphyletic relationship of nectarivorous phyllostomid bats. Our phylogenetic reconstructions indicate that the nectarivorous genera Lonchophylla and Lionycteris are closer related to mainly frugivorous phyllostomids of the subfamilies Rhinophyllinae, Stenodermatinae, Carolliinae, and the insectivorous Glyphonycterinae rather than to nectarivorous bats of the Glossophaginae. This suggests an independent origin of morphological adaptations to a nectarivorous lifestyle within Lonchophyllinae and Glossophaginae. Molecular clock analysis revealed a relatively short time frame of about ten million years for the divergence of subfamilies.

Conclusions: Our study provides strong support for diphyly of nectarivorous phyllostomids. This is remarkable, since their morphological adaptations to nutrition, like elongated rostrums and tongues, reduced teeth and the ability to use hovering flight while ingestion, closely resemble each other. However, more precise examinations of their tongues (e.g. type and structure of papillae and muscular innervation) revealed levels of difference in line with an independent evolution of nectarivory in these bats.
\end{abstract}

\section{Background}

The diversity of feeding specialization of phyllostomid bats are unique among all mammals [1-7]. They range from insect-to diverse vegetable-feeding strategies, as well as omnivory, carnivory, and even blood-feeding [816]. This ecological diversification is accompanied by morphological, behavioural and physiological adaptations $[4,9,17-32]$. A striking example is specialization for nectarivory, with several species feeding primarily on nectar. These bats have the ability to hover in front of a plant, while drinking nectar with their elongated and extensile tongues adorned with brush-like papillae and grooves for ingestion of nectar [3,26,29,30,33-37]. They digest and metabolize nectar and pollen quickly $[32,38-$

\footnotetext{
* Correspondence: thomas.datzmann@senckenberg.de

${ }^{1}$ Museum für Naturkunde, Leibniz Institute for Research on Evolution and Biodiversity at the Humboldt University Berlin, Invalidenstr. 43, 10115 Berlin, Germany

Full list of author information is available at the end of the article
}

44]. Phyllostomid bats represent the second largest chiropteran family after the vesper bats (Vespertilionidae Gray, 1821), with more than 150 species in at least 49 genera. Their distribution ranges from southern Arizona and the West Indies to northern Argentina [45].

Although phylogenetic analyses of morphology, chromosomes, and molecules have helped to illuminate relationships among many genera and subfamilies of phyllostomid bats, relationships among nectarivorous genera are still unclear. Many phylogenies based on morphological characters suggest a monophyletic origin for all specialized nectarivorous phyllostomids $[5,46,47]$. We provide a well-supported phylogenetic estimate of phyllostomid bats based on a large molecular data set, comprising 10396 bp from a total of twelve nuclear-and mitochondrial genes, and try to clarify phylogenetic relationships among nectarivorous taxa by testing whether they share a close common ancestry. Furthermore, we 
used a molecular clock approach to evaluate the evolutionary time frame of diversification in phyllostomid bats.

\section{Results}

\section{Phylogeny of the Phyllostomidae}

Figure 1 shows our maximum-likelihood reconstruction (b) compared to the latest comprehensive analysis of phyllostomid phylogeny (a) after Baker et al. (2003) [48]. Baker and colleagues used sequences of $12 \mathrm{~S}$ and $16 \mathrm{~S}$ rRNA, tRNA Valin and the rag2 gene for their inference. Our reconstruction shows high congruence, even though it is completely based on independent genes (see methods section: Alignment 1). Although no members of the subfamilies Lonchorhinae, Glyphonycterinae and Rhinophyllinae were included (because of incomplete data for these taxa), major branching patterns were consistently reconstructed. Our reconstruction received good bootstrap support and is in line with Baker et al.'s phylogeny of phyllostomid bats. Therefore, we combined our data with the data from Baker et al. (2003) [48].

A separate analysis of all mitochondrial and nuclear loci (Alignment 2\&3) resulted in high congruent phylogenies (Figure 2). Among the frugivorous species relationships changed between the independent inferences. A sistergroup relationship between Carolliinae and Glyphonycterinae could not be inferred from the mitochondrial data set. In this reconstruction glyphonycterids were found basal to all frugivores. But this relationship obtained low support (BS 50) compared to the reconstruction based on nuclear loci, where Carolliinae is sister taxon to them (BS 73).

Maximum likelihood (ML) analysis based on our supermatrix (see methods section: Alignment 5) revealed a well-resolved phylogeny for the Phyllostomidae (Figure 3 ), with most nodes receiving high bootstrap support (BS $>90$ ). Monophyly of all subfamilies recognized by Baker et al. (2003) [48] was verified, and relevant nodes were highly supported by different measurements (Table 1).

Three basal lineages, comprising the taxa Macrotus (1), Micronycteris (2), and the vampire bats Desmodus and Diaemus (3), were confirmed (Figure 3). A bifurcation in more or less omnivorous bats (Phyllostominae) and predominantly vegetarian species followed. Within the frugivores a sister-group relationship between Rhinophyllinae and the Stenodermatinae was well-supported (BS 99). However, support for a sister-group relationship of Carol-

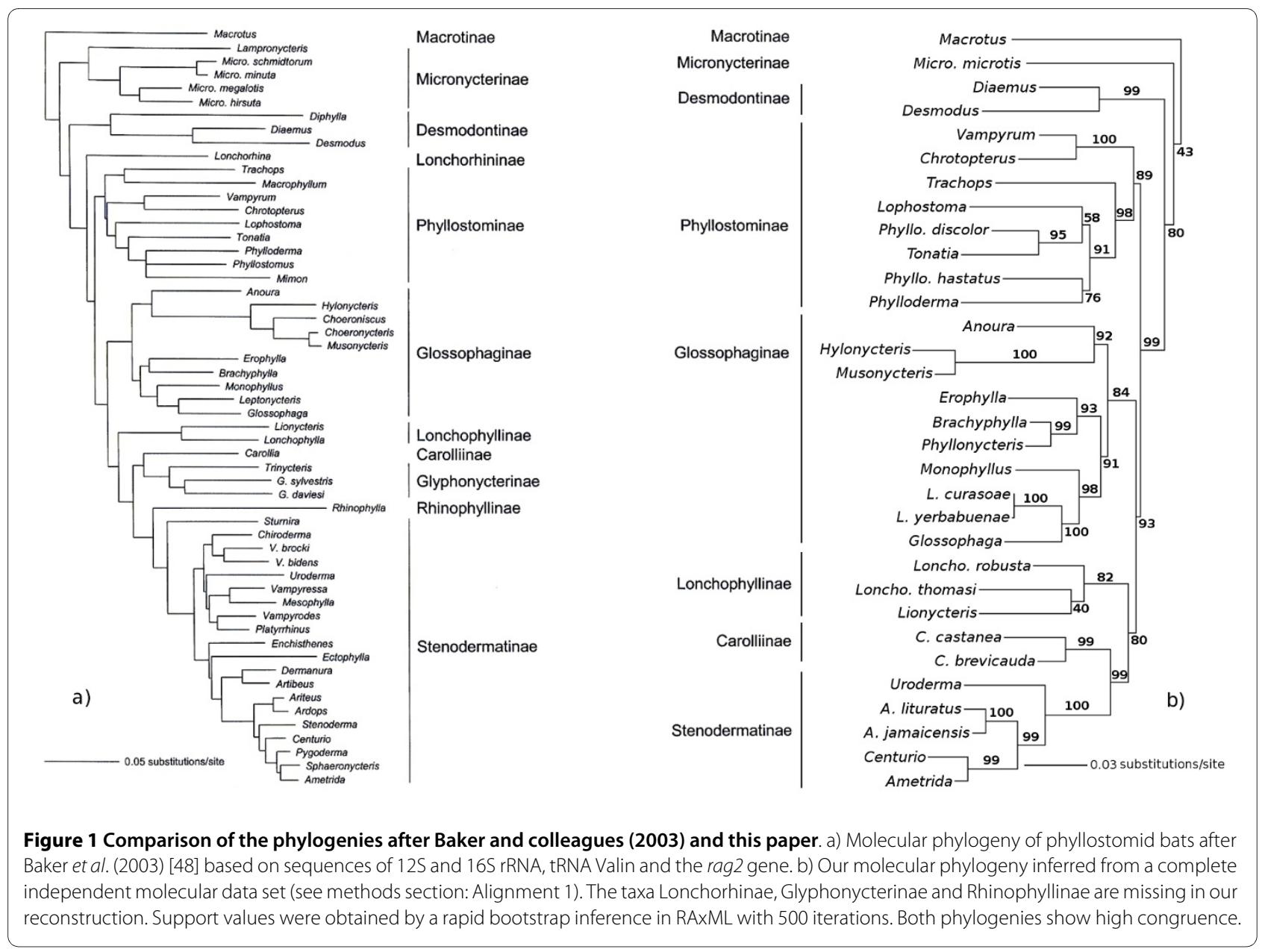




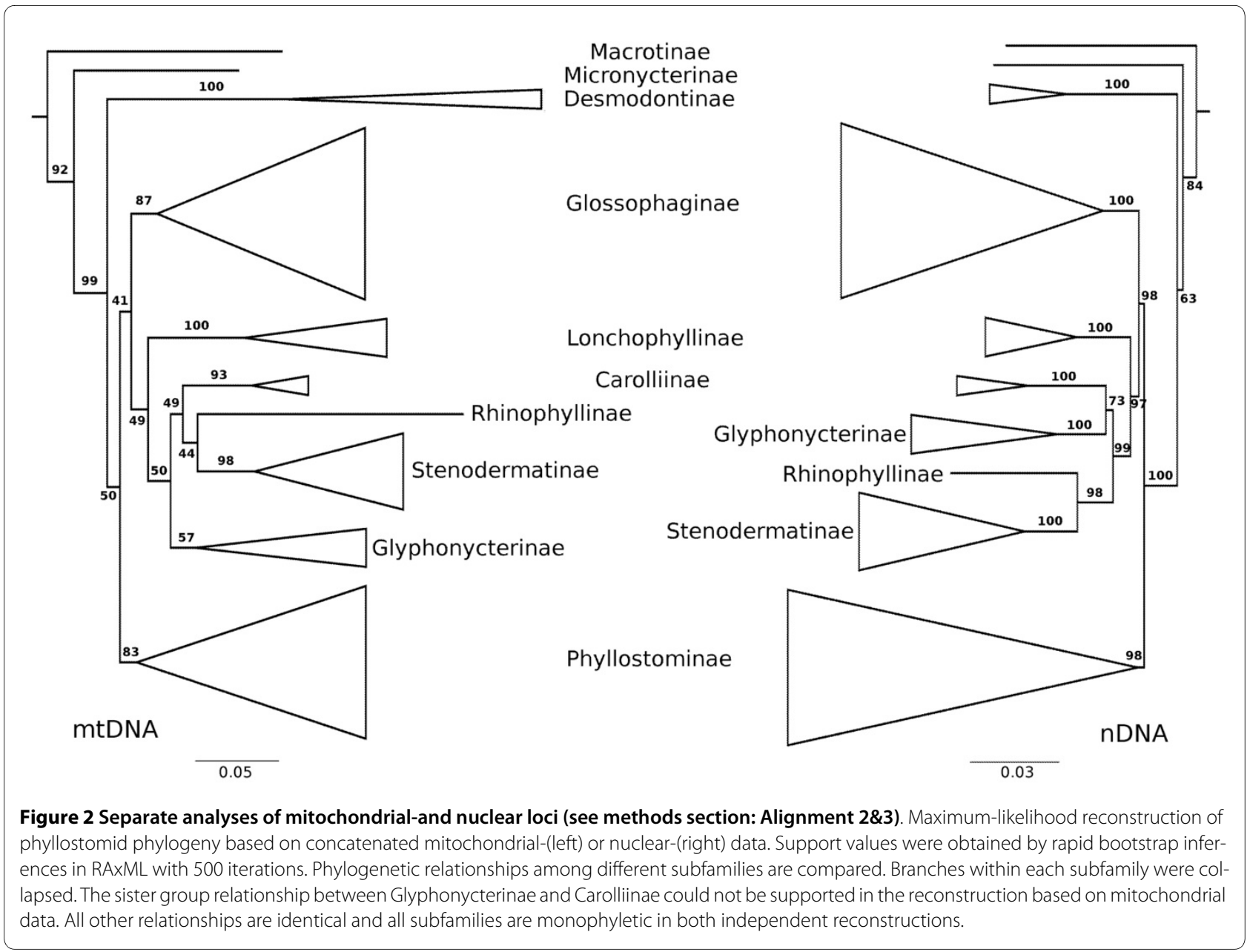

liinae and Glyphonycterinae was weak (BS 48). The highly specialized nectarivorous taxa Lonchophylla and Lionycteris do not align closely with other nectarivorous phyllostomids (Glossophaginae). Instead, they shared a common ancestor with the frugivores, as previously proposed by Baker et al. (2003) [48] and others [33,49,50].

\section{Divergence time estimation and model decision}

The analysis under the lognormal relaxed clock model (UCLN) produced the smallest confidence intervals compared to the exponential-(UCED) or strict clock model (CLOC). Estimates of mean likelihood, substitution rate, and node age were most accurately inferred under the UCLN model (Table 2). The assumption of the relaxed clock, that branches differ in their substitution rates, was confirmed. A coefficient of variation of 0.405 indicated moderate rate variation [51]. Figure 4 shows the dated Bayesian tree inferred with BEAST under the UCLN model. The common ancestor of all phyllostomids was dated to the Middle Eocene (42 MYA), with a confidence interval between 49- and 37 MYA. Basal lineages within the phyllostomids arose shortly thereafter in the Late
Eocene or Early Oligocene (35-32 MYA). The prominent amount of the remaining lineages emerged in a time frame of about ten million years at the transition from Oligocene to Miocene (29-20 MYA), with 21 out of 33 lineages already present in the Early Miocene (20 MYA).

\section{Reconstruction of ancestral states}

Figure 3 shows the reconstruction of ancestral states by the maximum-likelihood approach under the Markov kstate model. Only relevant nodes, which will be used in the discussion chapter, are shown. Reconstructed feeding specialization of the common ancestor of all phyllostomids and of the common ancestor of important clades were mapped on the tree (Figure 3). Unambiguous character states were assigned to nodes with a probability of more than $90 \%$ for one reconstructed state. The feeding specialization of the common ancestor of all omnivorous and predominantly vegetarian phyllostomid species could not be resolved, as the reconstruction was ambiguous for this node (marked with ?). We obtained probability values of $47 \%$ for a nectarivorous-, $39 \%$ for an omnivorous-, and $12 \%$ for an insectivorous state at this node. 


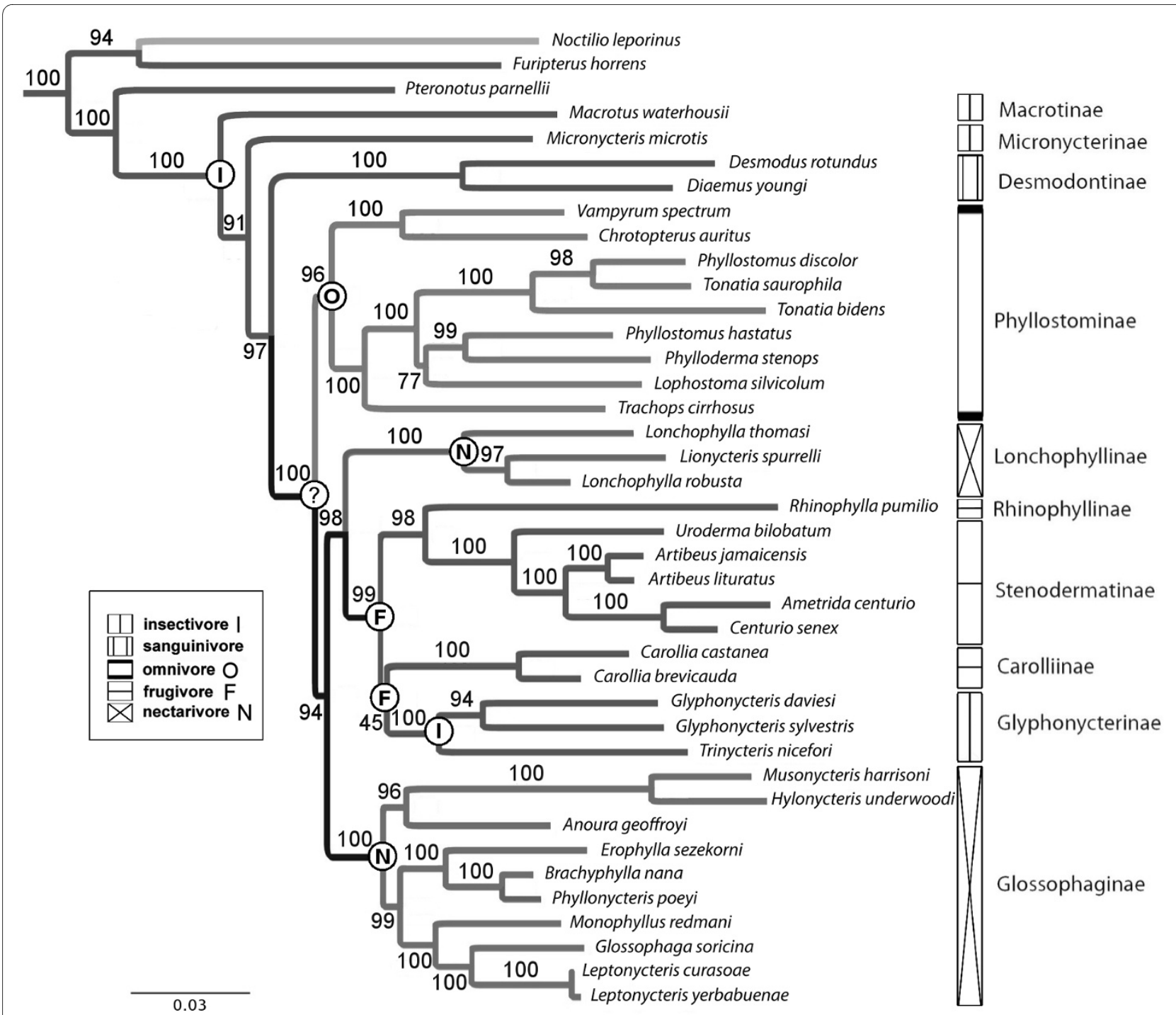

Figure 3 Maximum-likelihood estimate of phyllostomid phylogeny. Best maximum-likelihood tree obtained with RAxML v7.0.4 (see methods section: Alignment 5). The family Phyllostomidae (ten subfamilies) and representatives of closely related chiropteran families Noctilionidae, Furipteridae and Mormoopidae are shown. Further outgroup taxa (Molossidae, Vespertilionidae, Rhinolophidae) are not shown. Support values were obtained by a full non-parametric bootstrap search with 2500 iterations. Symbols refer to feeding specialization of different terminal lineages $[5,61,115,116]$ and circles at some nodes indicate reconstructed states for their ancestors. One reconstruction obtained an ambiguous result (marked with ?).

\section{Discussion}

\section{Phylogeny of the Phyllostomidae}

Our molecular phylogenetic reconstructions based on more than $10 \mathrm{~kb}$ DNA sequences obtained high bootstrap support for almost all nodes and challenges several phylogenetic relationships derived from morphological data sets. Our results partly disagree with recent classifications of phyllostomid bats [45,49] including: (1) placement of insectivorous genera Macrotus, Micronycteris, Glyphonycteris and Trinycteris within the Phyllostomidae; (2) relationship of the fruit-eating genus Rhinophylla to other frugivores; and (3) relationships among nectarivorous phyllostomids.
The molecular data suggest that the genera Macrotus and Micronycteris do not belong to the subfamily Phyllostominae as proposed by Koopman (1994) [49], McKenna and Bell (1997) [47], Wetterer et al. (2000) [5], and Jones et al. (2002) [50]. Instead, they form two divergent basal lineages within phyllostomid bats (Figure 3). Our data are in line with the findings of Baker et al. (2003) [48]. The authors proposed a classification of two different subfamilies Macrotinae and Micronycterinae. Three studies placed the genera Glyphonycteris and Trinycteris within the subfamily Phyllostominae $[5,45,49]$. In contrast, our data revealed a close relationship of Glyphonycteris and Trinycteris with frugivorous species of the subfamily Car- 
Table 1: Clade stability measures.

\begin{tabular}{|c|c|c|c|c|c|c|}
\hline Subfamilies Phyllostomidae & posterior & BS & DI & GMYC & $\begin{array}{l}\text { branch } \\
\text { length }\end{array}$ & $\begin{array}{l}\text { congruence } \\
\text { index }\end{array}$ \\
\hline Macrotinae & n.a. & n.a. & n.a. & n.a. & 0.086 & 1.0 \\
\hline Micronycterinae & n.a. & n.a. & n.a. & n.a. & 0.073 & 1.0 \\
\hline Desmodontinae & 1 & 100 & 64 & yes & 0.049 & 1.0 \\
\hline Phyllostominae & 1 & 99 & 3 & yes & 0.004 & 0.6 \\
\hline Lonchophyllinae & 1 & 100 & 27 & yes & 0.031 & 1.0 \\
\hline Rhinophyllinae & n.a. & n.a. & n.a. & n.a. & 0.090 & 1.0 \\
\hline Stenodermatinae & 1 & 100 & 28 & no & 0.023 & 0.6 \\
\hline Carolliinae & 1 & 100 & 25 & yes & 0.034 & 1.0 \\
\hline Glyphonycterinae & 1 & 100 & 8 & yes & 0.013 & 0.6 \\
\hline Glossophaginae & 1 & 100 & 36 & no & 0.014 & 0.6 \\
\hline
\end{tabular}

Different measures were calculated to describe clade stability: posterior probability, bootstrap value (BS), decay index (DI), Bayesian cluster recognition (GMYC) and branch length. Further, trophic level of the bats was also considered (Figure 3). Decay indices were obtained with TreeRot.v3 [117] in combination with the phylogenetic software PAUP 4.0 beta [89]. A decay index greater than ten is considered as strong support for a specific node. Automated cluster recognition via the "Generalized Mixed Yule-Coalescent" (GMYC) approach with multiple threshold extension was used [118-120]. Branches longer than the mean branch length (0.03 substitutions per position) are considered as long. Congruence indices were calculated by the number of useable support measures for a specific node divided by the number of cases in which there was high support.

olliinae. Despite low support for this sister-group relationship (BS 45), our data support a closer relationship of Glyphonycteris and Trinycteris to fruit-eating species (BS 99) than to omnivorous phyllostomids of the subfamily Phyllostominae.

The genus Rhinophylla does not belong to the subfamily Carolliinae, as proposed by McKenna and Bell (1997) [47], Wetterer et al. (2000) [5], and Jones et al. (2002) [50]. Our data support a sister-group relationship between Rhinophylla and the subfamily Stenodermatinae, as proposed by Baker et al. (2003) [48].

Many authors excluded the genera Phyllonycteris, Erophylla and Brachyphylla, all endemic to the West Indies, from other nectarivorous phyllostomids and placed them mostly into the subfamilies Phyllonycterinae and Brachyphyllinae $[3,5,19,33,45,49,50,52-59]$. In contrast, our data show that these nutritionally more generalized bats belong to the Glossophaginae (BS 100). The three genera are closely related to more specialized nectarivorous bats of the genera Glossophaga, Leptonycteris and Monophyllus. This is in line with an earlier molecular phylogeny of Baker et al. (2003) [48]. The phylogenetic position of highly specialized nectarivorous bats of the genera Lonchophylla and Lionycteris is controversial. Several studies, primarily based on morphological analyses, placed them within the Glossophaginae [5,46,47,52]. Instead, our molecular data suggest that they are closer related to Rhinophyllinae, Stenodermatinae, Carolliinae, and Glyphonycterinae than to the Glossophaginae. This finding is in line with previous studies of Koopman (1994) [49], Jones et al. (2002) [50] and Baker et al. (2003) [48]. The distinctness of Lonchophyllinae is also supported by fixed differences in the tongue morphology (see below) between representatives of the Lonchophyllinae and Glossophaginae [33].

In summary, our study supports the classification of phyllostomid bats after Baker et al. (2003) [48]. Their division into more subfamilies, compared to Koopman (1994) [49] and Simmons (2005) [45], seems justifiable, because this better reflects the remarkable ecological diversity of this family.

\section{Dietary diversification}

The vast majority of bats feed on insects [4]. This includes the family Mormoopidae, which represents the sister group of the Phyllostomidae. In addition, the diet of the most basal subfamilies Macrotinae and Micronycterinae consists mainly of insects (Figure 3). These findings indicate, that the common ancestor of phyllostomid bats was an insect-feeder. This supposition is also supported by the maximum-likelihood reconstruction of the ancestral state (Figure 3).

Members of the Phyllostominae have a mixed diet. The reconstruction of the ancestral state for this group revealed that their physiological pre-adaptations to omnivory could have evolved only once, and involved metabolic changes from insectivorous to an omnivorous diet. However, too little is known about the diet of these bats. A high spacial and seasonal plasticity is observed [60]. A few members of the Phyllostominae are carnivo- 


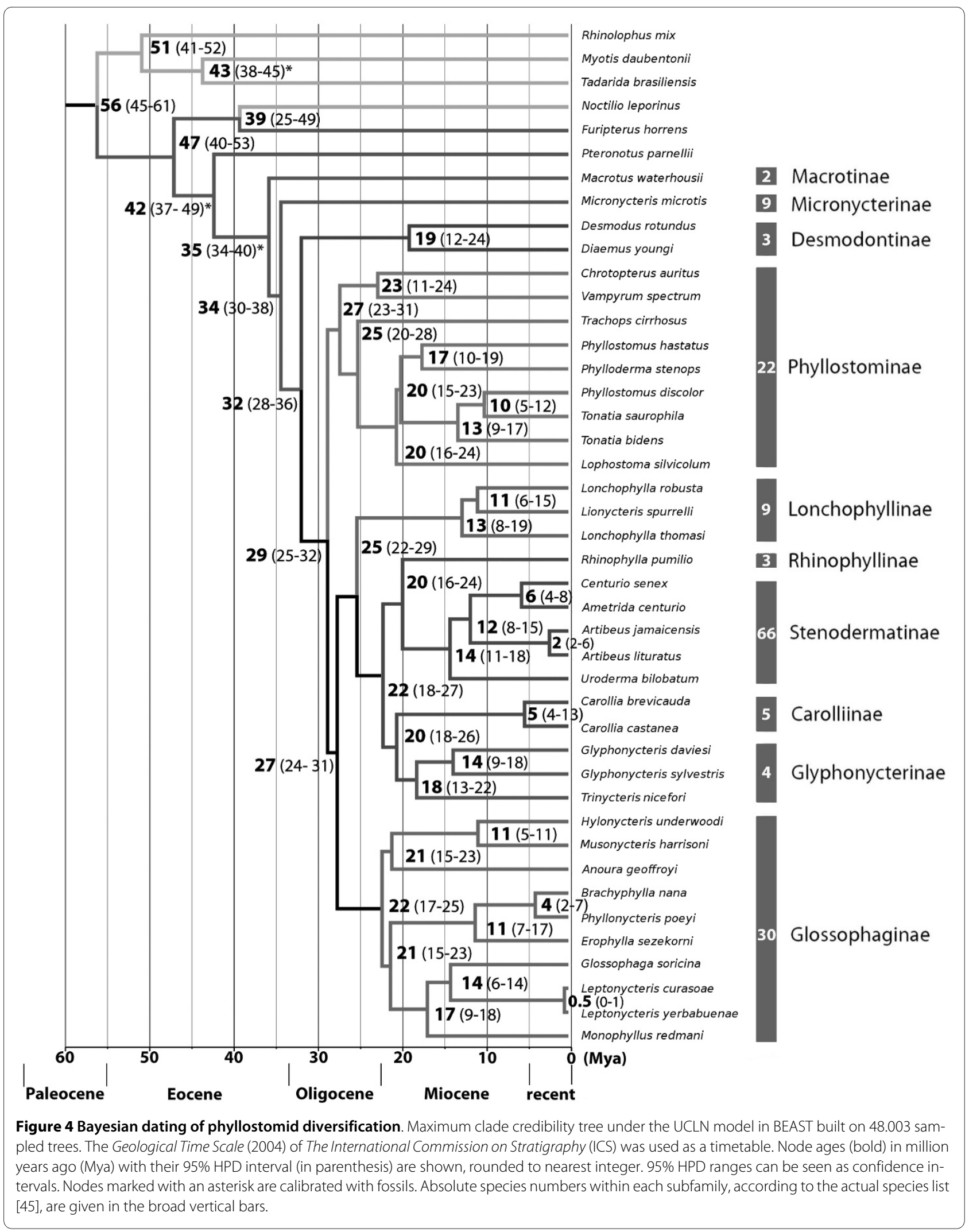


Table 2: Model comparison.

\begin{tabular}{|c|c|c|c|c|c|c|}
\hline \multirow[t]{2}{*}{ Molecular Clock Model } & \multicolumn{3}{|c|}{ CLOC - 3 priors } & \multicolumn{3}{|c|}{ CLOC (without data) } \\
\hline & mean & $<95 \%$ HPD & > 95\% HPD & mean & $<95 \%$ HPD & $>95 \%$ HPD \\
\hline Likelihood & $-8.42 E+004$ & $-8.42 E+004$ & $-8.42 E+004$ & - & - & - \\
\hline rate $\left[{ }^{* *}\right]$ & $1.40 \mathrm{E}-003$ & $1.28 \mathrm{E}-003$ & $1.52 \mathrm{E}-003$ & 50.3 & 4.82 & 99.61 \\
\hline rootHeight $\left[{ }^{*}\right]$ & 61.04 & 56.42 & 66.05 & 60.75 & 40.81 & 86.73 \\
\hline $\begin{array}{l}\text { Molossidae } \times \\
\text { Vespertilionidae p1 }\left[^{*}\right]\end{array}$ & 39.32 & 37.49 & 41.64 & 41.15 & 37.64 & 46.01 \\
\hline $\begin{array}{l}\text { Mormoopidae } \times \\
\text { Phyllostomidae p2 }\left[{ }^{*}\right]\end{array}$ & 56.4 & 51.3 & 61.86 & 38.39 & 34.09 & 44.75 \\
\hline $\begin{array}{l}\text { Macrotus } \times \text { rest of } \\
\text { Phyllostomidae p3 }\left[{ }^{*}\right]\end{array}$ & 47.99 & 43.64 & 52.57 & 35.71 & 34 & 39.1 \\
\hline \multirow[t]{2}{*}{ Molecular Clock Model } & \multicolumn{3}{|c|}{ UCED - 3 priors } & \multicolumn{3}{|c|}{ UCLN - prior p1 } \\
\hline & mean & $<95 \%$ HPD & $>95 \%$ HPD & mean & $<95 \%$ HPD & $>95 \%$ HPD \\
\hline Likelihood & $-7.68 E+004$ & $-7.69 E+004$ & $-7.68 \mathrm{E}+004$ & $-7.68 E+004$ & $-7.68 \mathrm{E}+004$ & $-7.68 \mathrm{E}+004$ \\
\hline rate $\left[{ }^{* *}\right]$ & $3.96 \mathrm{E}-003$ & $3.04 \mathrm{E}-003$ & 4.81E-003 & $1.90 \mathrm{E}-003$ & $1.15 E-003$ & $2.73 \mathrm{E}-003$ \\
\hline rootHeight [*] & 62.9 & 42.24 & 90.14 & 81.84 & 51.92 & 116.2 \\
\hline $\begin{array}{l}\text { Molossidae } \times \\
\text { Vespertilionidae p1 }\left[{ }^{*}\right]\end{array}$ & 41.5 & 37.71 & 46.88 & 42.43 & 37.71 & 49.8 \\
\hline $\begin{array}{l}\text { Mormoopidae } \times \\
\text { Phyllostomidae p2 [*] }\end{array}$ & 39.24 & 34.77 & 46.91 & 77.49 & 54.67 & 104.63 \\
\hline $\begin{array}{l}\text { Macrotus } \times \text { rest of } \\
\text { Phyllostomidae p3 }\left[{ }^{*}\right]\end{array}$ & 35.49 & 34 & 38.5 & 67.49 & 37.86 & 100.44 \\
\hline \multirow[t]{2}{*}{ Molecular Clock Model } & \multicolumn{3}{|c|}{ UCLN - prior p2 } & \multicolumn{3}{|c|}{ UCLN - prior p3 } \\
\hline & mean & $<95 \%$ HPD & $>95 \%$ HPD & mean & $<95 \%$ HPD & $>95 \%$ HPD \\
\hline Likelihood & $-7.68 \mathrm{E}+004$ & $-7.68 \mathrm{E}+004$ & $-7.68 \mathrm{E}+004$ & $-7.68 \mathrm{E}+004$ & $-7.68 \mathrm{E}+004$ & $-7.68 \mathrm{E}+004$ \\
\hline rate $[* *]$ & 4.09E-003 & 3.09E-003 & $4.95 E-003$ & $3.50 \mathrm{E}-003$ & $2.94 \mathrm{E}-003$ & 4.07E-003 \\
\hline rootHeight $\left[{ }^{*}\right]$ & 38.32 & 30.94 & 49.32 & 42.73 & 34.99 & 51.79 \\
\hline $\begin{array}{l}\text { Molossidae } \times \\
\left.\text { Vespertilionidae p1 }{ }^{*}{ }^{*}\right]\end{array}$ & 22.89 & 12.51 & 34.16 & 22.39 & 12.97 & 33.52 \\
\hline $\begin{array}{l}\text { Mormoopidae } \times \\
\text { Phyllostomidae p2 }\left[{ }^{*}\right]\end{array}$ & 34.99 & 30.37 & 42.93 & 37.1 & 28.73 & 46.06 \\
\hline $\begin{array}{l}\text { Macrotus } \times \text { rest of } \\
\text { Phyllostomidae p3 }\left[^{*}\right]\end{array}$ & 29.07 & 23.35 & 37.01 & 35.81 & 34 & 39.43 \\
\hline \multirow[t]{2}{*}{ Molecular Clock Model } & \multicolumn{3}{|c|}{ UCLN - 2 priors $p 1+p 3$} & \multicolumn{3}{|c|}{ UCLN - 3 priors } \\
\hline & mean & $<95 \%$ HPD & > 95\% HPD & mean & $<95 \%$ HPD & $>95 \%$ HPD \\
\hline Likelihood & $-7.68 E+004$ & $-7.68 \mathrm{E}+004$ & $-7.68 \mathrm{E}+004$ & $-7.68 \mathrm{E}+004$ & $-7.68 \mathrm{E}+004$ & $-7.68 \mathrm{E}+004$ \\
\hline rate $[* *]$ & $3.04 \mathrm{E}-003$ & $2.58 \mathrm{E}-003$ & $3.43 E-003$ & 3.13E-003 & $2.76 \mathrm{E}-003$ & $3.48 \mathrm{E}-003$ \\
\hline rootHeight $\left[{ }^{*}\right]$ & 53.85 & 45.94 & 63.48 & 52.26 & 45.42 & 61.28 \\
\hline $\begin{array}{l}\text { Molossidae } \times \\
\text { Vespertilionidae p1 }\left[{ }^{*}\right]\end{array}$ & 40.99 & 37.7 & 45.85 & 40.89 & 37.64 & 45.39 \\
\hline
\end{tabular}


Table 2: Model comparison. (Continued)

\begin{tabular}{|c|c|c|c|c|c|c|}
\hline $\begin{array}{l}\text { Mormoopidae } \times \\
\text { Phyllostomidae p2 [*] }\end{array}$ & 44.56 & 37.34 & 53.21 & 42.16 & 37.13 & 48.61 \\
\hline $\begin{array}{l}\text { Macrotus } \times \text { rest of } \\
\text { Phyllostomidae } \mathrm{p} 3\left[^{*}\right]\end{array}$ & 36.96 & 34 & 42.72 & 35.82 & 34 & 39.58 \\
\hline
\end{tabular}

Divergence time estimations of specific nodes under different molecular clock models and different calibration settings are shown. Strict- (CLOC), relaxed exponential- (UCED) and relaxed lognormal- (UCLN) clock models are compared. Likelihood value, mean mutation rate, root age and time to the most recent common ancestor (tMRCAs) of taxon subsets are given. $\left[^{*}\right]$ Estimated age of taxon subset in million years ago (Mya). ${ }^{* *}$ ] Estimate of the evolutionary rate across the whole tree in units of substitutions per site per million years (Myr). $<>$ Lower and upper bound of the $95 \%$ highest posterior density (HPD) interval. 95\% HPD is the shortest interval, that contains $95 \%$ of the sampled values and is equivalent to a confidence interval.

rous and feed on small vertebrates [61]. For example, Trachops cirrhosus is specialized on tungara frogs $[62,63]$. Such a unique specialization likely evolved in a formerly insectivorous/omnivorous species. It was shown, for the seasonally carnivorous Greater Noctule bat (Nyctalus lasiopterus, Vespertilionidae), that only minor changes are needed to switch from insectivory to carnivory (inclusion of small vertebrates in the diet) $[64,65]$. The transition from large-bodied insects to small vertebrates as prey does not need any major adaptations and occurred several times independently in different bats and is correlated with an increase in body size [61].

A large number of phyllostomid species have a vegetarian diet. They form a monophyletic clade (BS 99), comprising the subfamilies Rhinophyllinae, Stenodermatinae, Carolliinae, Glossophaginae, Lonchophyllinae, and surprisingly the Glyphonycterinae. The last subfamily includes several strict insectivorous species; thus, a shift from a vegetarian diet back to insectivory seems to be the most plausible scenario. Alternatively, the Glyphonycterinae retained the ancestral insectivorous lifestyle. This assumption would require that the frugivorous subfamilies Rhinophyllinae, Stenodermatinae and Carolliinae have evolved their feeding specialization independently from each other. However, the relevant node is weakly supported in our phylogenetic reconstruction. It is also possible (see Figure 2 based on mitochondrial data) that the Glyphonycterinae represents a basal lineage to all frugivores and therefore possess the plesiomorphic state for this group. The common ancestry of all frugivore species was also postulated by previous studies $[5,46,48,50,59]$. However, there is a high dietary plasticity in this group. For example, Carollia is a known switch hitter between fruits and insects depending on the season (summarized in

[66]).

The diphyly of the nectarivorous Lonchophyllinae and Glossophaginae is surprising, since they resemble each other in many morphological, behavioural, ecological, and physiological traits (e.g. skull elongation, reduction of dentition, hovering flight, forest foraging behaviour and ability to metabolize pollen). Accordingly, these similari- ties have evolved independently by natural selection during the adaptation to a nectar-feeding lifestyle. This hypothesis is supported by some obvious differences in these adaptive traits [33]: The lonchophyllines have a deep longitudinal groove in their tongue, lined dorsal and ventral with hairlike papillae. This groove is missing in the glossophagines and hairlike papillae are distributed anterodorsal, forming a brush tip. Furthermore, the lonchophyllines lost most types of papillae found on the tongues of other phyllostmids, including the glossophagines. Also, the internal tongue structure is very different. The lonchophyllines have complex, omnidirectional bundles of muscles within the tongue, while glossophagines have predominantly horizontal skeletal muscle bundles. The complex orientated muscles in the lonchophyllines are supposed to control the shape of the groove during nectar feeding [33]. Drinking behaviour varies widely between both subfamilies (Marco Tschapka, pers. comm., [30]). Other characters show similar apomorphic states in lonchophyllines and some glossophagines (e.g. posterior shift of sternohyoid origin, xiphoid origin of sternohyoid, elongated hyoglossus and loss of connection to hyoid bone, double insertion of geniohyoid, posterior shift of genioglossus insertion [33]), however, there are no consistent patterns. The endemic West Indian genera, Brachyphylla, Erophylla, and Phyllonycteris, show many plesiomorphic characters. It seems that functional constraints on the muscular innervation of the tongue curtain the evolutionary signals of these characters. Hence, it is possible that lonchophyllines and glossophagines may have evolved these adaptations for nectar-feeding independently (but see also $[67,68]$ ).

The large number of species within the clade of frugivorous and nectarivorous bats (Figure 2) suggests, that a shift to a vegetarian diet accelerated the diversification rates in this group. The majority of phyllostomid bats, 117 out of 158 listed species [45], i.e. 74\%, belong to this clade. Possibly the presence of numerous vacant ecological niches in tropical and subtropical regions of America (see also [69]) resulted in allopatric speciation. 


\section{Time frame of evolution}

Our analysis revealed a time frame of ten million years (29-20 MYA) from Oligocene to Early Miocene, in which all prominent lineages evolved (Figure 4). Most of the species diversification occurred subsequent to the Oligocene epoch (since 23 MYA). During the Miocene substantial changes of the landscape occurred in Tropical America due to massive plate tectonics [70-75]. Global climate cooled and resulted in an increase in aridity [7678]. Frequent isolation events could have resulted in allopatric populations and thus promoted speciation [79]. Interestingly, the radiation of extant hummingbirds (Trochilidae), another alimentary competitor, shows a similar pattern of diversification in the Middle Miocene [80]. Geologic upheavals as well as the ability of ecologically generalized species to invade new regions were considered as major forces promoting hummingbird radiations in newly arisen montane regions. In order to test whether these factors has also promoted speciation in bats, and to infer other underlying evolutionary mechanisms, a much denser taxon sampling is required.

\section{Conclusions}

Our analysis of more than 10.000 base pairs of concatenated DNA sequences reveals a strongly supported phyllostomid phylogeny, thus allowing for clear predictions about the evolution of feeding specialization of these bats. Several morphological and even molecular studies were unable to resolve the specific branches with sufficient support, either due to the convergent nature of the analyzed characters or insufficient amount of sequence data. Our multi-gene approach, combined with a relaxed clock analysis, detected and dated major splitting events within this family. This study gives support for the classification of phyllostomid bats after Baker et al. (2003) [48]. All prominent lineages with diverse feeding strategies evolved within a relatively short time frame of about ten million years from Oligocene to Early Miocene. Geological and climate changes as well as the shift to a vegetarian diet may have promoted the radiation into diverse lineages. In this context, the diphyly of the nectarivorous Lonchophyllinae and Glossophaginae is remarkable. Despite many similarities between both groups, it seems plausible, that they evolved their adaptations to nectarivory independently from each other. This would represent an example of convergent evolution within bats that led to very similar features, which play a major role in food acquisition.

\section{Methods}

\section{Taxon sampling}

Thirty-seven phyllostomid species of 29 genera were analyzed. Our sampling comprises members of all extant subfamilies $[45,49]$, except bats of the subfamily Lon- chorhinae. We used species and subfamily assignments according to Baker et al. (2003) [48]. One representative each of the families Mormoopidae, Furipteridae, Noctilionidae, Molossidae and Vespertilionidae were used as outgroup taxa. Two closely related specimens were used for the family Rhinolophidae, because we were not able to analyze all loci entirely for one taxon. GenBank accession numbers are given in addtitional file 1. Tissue samples were provided by cooperation partners (see acknowledgements). The name of the body which gave approval and corresponding reference numbers could be obtained from them.

\section{Genetic analyses}

Extraction of total genomic DNA was done by Chloroform-Isoamyl-Phenol precipitation. A $1.3 \mathrm{~kb}$ fragment of the exon 28 of the von Willebrand factor gene $(\nu w f)$ was amplified with the primers vWF-A and vWF-B [81], or with vWF-A and vWF-B2 [81] within a Nested PCR. Primer vWF-B2 anneals 139 bp upstream from vWF-B. An approximately $1.4 \mathrm{~kb}$ fragment of the recombination activating gene 2 ( $r a g 2)$ was amplified with the primers RAG2-F1 and RAG2-R2 [59], or with RAG2-F1B and RAG2-R2 [59]. The PCR Mastermix (25 $\mu l$ final reaction volume) included $2 \mu \mathrm{l}$ of total genomic DNA extract, 1.25 $\mu l$ of each primer $(10 \mu M), 1 \mu l$ of $\mathrm{MgCl}_{2}(25 \mathrm{mM}), 1 \mu l$ of a dNTP-Mix $(10 \mathrm{mM})$ and 1 unit of Peglab Taq polymerase. Nested PCR was performed using $2 \mu l$ from a 1:40 delution of the first PCR reaction. The fragments were amplified following a Two-Step protocol. Thermocycling consisted of a $3 \mathrm{~min}$ initial denaturation at $95^{\circ} \mathrm{C}$, followed by 5 cycles of $30 \mathrm{~s}$ at $95^{\circ} \mathrm{C}, 50 \mathrm{~s}$ at $65^{\circ} \mathrm{C}$ (for the $v w f$ ), or $30 \mathrm{~s}$ at $60^{\circ} \mathrm{C}$ (for the rag2), and $90 \mathrm{~s}$ at $72^{\circ} \mathrm{C} .35$ cycles with $50 \mathrm{~s}$ annealing at $62^{\circ} \mathrm{C}$ (for the $v w f$ ) and 30s at $57^{\circ} \mathrm{C}$ (for the rag2) were performed, followed by a final extension of $6 \mathrm{~min}$ at $72^{\circ} \mathrm{C}$. A fragment of exon 11 of the breast cancer susceptibility gene (brca1) was amplified with the primers BRCA1-F126 [82] and a newly designed (ER 515: 5' - AAGTGTTGGAAGCAGGGAAGCTCTTC3 ). The PCR-Mastermix (50 $\mu l$ final reaction volume) included $2 \mu l$ of total DNA extract, $2.5 \mu l$ of each primer $(10 \mu M)$ and $25 \mu l$ Phusion Mastermix. Thermocycling consisted of a 30s initial denaturation at $98^{\circ} \mathrm{C}$, followed by 5 cycles of $10 \mathrm{~s}$ of $98^{\circ} \mathrm{C}, 25 \mathrm{~s}$ at $66^{\circ} \mathrm{C}$, and $90 \mathrm{~s}$ at $72^{\circ} \mathrm{C} .30$ cycles with $25 \mathrm{~s}$ annealing at $63^{\circ} \mathrm{C}$ were performed, followed by a final extension of $6 \mathrm{~min}$ at $72^{\circ} \mathrm{C}$. Two non-coding nuclear loci were also analyzed: 3'-UTR region of the phospholipase $\mathrm{C}$ beta 4 gene (plcb4) [83] and short intron of the phosphoenolpyruvate carboxykinase gene (pepck) [84];

We amplified a mitochondrial fragment of the NADH dehydrogenase subunit 1 gene (nd1) and the tRNA Leucin, using the primers ER 65 and ER 66 [85]. Published sequences of five additional mitochondrial loci (COI, 
Cytb, 12S rRNA, 16S rRNA and tRNA Valin) were incorporated. For all analyses, the ribosomal RNAs and the tRNA Valin were combined (12StRNA16S). Accession numbers are given in Additional file 1. It also includes an overview of all incorporated taxa, loci and sequences and the percentage of missing data per species, as well the geographic origin of our samples. The overall amount of missing data is about $30 \%$.

\section{Alignments and model selection}

All alignments were done with Sequencher v4.7 [86] and Bioedit v7.0.9 $[87,88]$ and checked manually by eye. We performed bootstrap analyses of each individual loci to check for compatibility of their individual phylogenetic signal. Because none of the strongly supported clades based on individual loci were mutually incompatible, we concatenated all loci except the ribosomal RNAs, tRNA Valin and the rag2 gene. These loci were already used by Baker and colleagues to infer a molecular phylogeny of phyllostomid bats [48]. We avoided in a first step the inclusion of them to get an independent data set [Alignment 1]. In a second step we concatenated all mitochondrial loci (this time with the inclusion of the ribosomal RNAs and the tRNA Valin) [Alignment 2] and also all nuclear loci (with rag2) [Alignment 3]. We concatenated all loci into one supermatrix for the final analyses. The supermatrix contained three nuclear protein-coding genes (rag2, vwf and brca1), two non-coding nuclear markers (pepck, plcb4), three mitochondrial protein-coding genes (co1, cytb and nd1), two tRNAs (Valin, Leucin) and two mitochondrial rRNAs (12S, 16S). For the Bayesian analyses, we excluded all 3rd codon positions in the mitochondrial protein-coding genes because they showed a high degree of homoplasy (homoplasy index, $\mathrm{HI}=0.75$ - parsimony analysis of the $3 \mathrm{rd}$ codon positions in PAUP 4.0 beta [89]). Such high homoplastic characters give a misleading phylogenetic signal and lead especially to an underestimation of real branch lengths. Therefore, we excluded them from the analyses. This resulted in a final length of $10396 \mathrm{bp}$, including 2761 parsimony informative characters [Alignment 4 - Additional file 2]. For the maximum-likelihood analyses, we used a second alignment, in which the mitochondrial protein-coding sequences were translated in amino acids and combined with the remaining DNA sequences [Alignment 5 - Additional file 3]. The best fitting evolutionary model for the protein data was inferred with Prottest v1.4 [90]. The MTMAM model, designed for the evolution of mitochondrial proteins of mammals [91], showed the highest fit. We ran jModelTest [92] for the remaining DNA sequences separate for the alignments 1-5. Except for alignment $3, \mathrm{GTR}+\Gamma$ [93] was proposed to be the best fitting evolutionary model according to Akaike- (AIC) and Bayesian (BIC) information criterion [94,95]. The slightly simpler Symmetrical Model SYM $+\Gamma$ [96] was proposed for alignment 3 by jModelTest. However, we also used the GTR $+\Gamma$ model for this data set for general compatibility among the inferences. Genes could have a different sequence evolution. Therefore, we generated five partitioning schemes [97] for alignment 5 to decide, which is the best adjustment for our analysis: (1) no partitioning; (2) mitochondrial- and nuclear loci separately; (3) three partitions; (4) eight partitions; and (5) 14 partitions with partitioning into codon positions for all nuclear genes. According to AIC and BIC, scheme 5 was preferred.

\section{Maximum-Parsimony analysis}

Equal weighted maximum-parsimony (MP) analyses were performed with PAUP 4.0 beta [89] with a heuristic search using the TBR (tree-bisection-reconnection) algorithm for branch swapping. Bootstrap inferences were conducted separately for each loci with 500 pseudoreplicates.

\section{Maximum-Likelihood analysis}

Maximum-likelihood (ML) inferences were performed with RAxML v7.0.4 [98-100]. ML searches were conducted with the rapid hill-climbing algorithm $[101,102]$ under GTR $+\Gamma$ with four rate categories as model of evolution. Multiple independent runs were started to get an impression of the robustness of the phylogenetic reconstruction. Support values were obtained through a full non-parametric bootstrap- or rapid bootstrap inference (stated for each analysis).

\section{Reconstruction of ancestral states}

Ancestral character states were reconstructed in Mesquite v2.71 [103]. Observed character states (insectivore, sanguinivore, omnivore, frugivore and nectarivore) of the main diet were mapped on the original maximum-likelihood tree (Figure 3). We used the "Trace Character History" analysis with a symmetric, one-parameter Markov k-state model [104,105], which computes likelihoods for categorical characters, and reconstructs ancestral states by the maximum marginal probability (MLE) criterion.

\section{Bayesian analysis}

Bayesian inferences were performed with BEAST v1.4.8 [106]. The searches were conducted under HasegawaKishino-Yano $\mathrm{HKY}+\Gamma$ [107] with four rate categories as model of evolution. We chose a simpler model of sequence evolution for the Bayesian analyses as proposed by jModelTest because there was a trade-off between computational power and model complexity. It was not possible to get a consistent phylogenetic reconstruction between different runs under the GTR $+\Gamma$ model in reasonable time. Bayes factor analysis between these runs under the GTR $+\Gamma$ model resulted always in values far above 20 and sampling efficiency was drastically reduced 
compared to the $\mathrm{HKY}+\Gamma$ model. A high Bayes factor is a sign for incompatibility and poor convergence among the trees gathered in independent runs.

\section{Calibration of the molecular clock}

We incorporated three different calibration points including: (1) divergence between Vespertilionidae and Molossidae set at 37 million years ago (MYA) in the Middle Eocene [47]; (2) age of the Mormoopidae oldest fossils from Whitneyan (30-32 MYA) land deposits in Florida [108]; and (3) age of the oldest crown group fossils of the phyllostomids in the Laventan about 11.8 to 13.8 MYA [109] and age of the oldest stem group fossils in the Whitneyan within the Early Oligocene [110]. We used the proposed age of the fossils and lognormal distributions to model minimum age constraints for the specific nodes $(1,2)$. Maxmimum age constraints were set to the Cretaceous-Tertiary boundary at 65 MYA $(1,2)$. Additional, a maximum age constraint for the phyllostomids (3) was set with an exponential distribution to 34 MYA with an arbitrarily lower limit of 11.5 MYA.

\section{Model- and prior decision}

We performed several Bayesian inferences under one strict (CLOC) and two relaxed (UCLN, UCED) molecular clock models $[111,112]$. Always 10 million steps were performed. We examined the joint influence of the calibrations on the divergence time estimates by running a strict clock model with fixed topology, but with no sequence data. Further, we examined the influence of each individual calibration by running several inferences under an uncorrelated lognormal relaxed clock model (UCLN) with all possible combinations of the three calibrations. A precise examination and comparison of the results were performed in Tracer v1.4 [113]. An overview of important parameters for model comparison is given in Table 2 . Important parameters, such as mean likelihood value, substitution rate, and node age, were calculated for every inference and compared with each other. Confidence intervals measured as $95 \%$ highest posterior density interval (HPD) were also computed. The clock model that produced the smallest confidence intervals altogether was considered most appropriate for the data [112].

\section{Estimation of divergence times}

We conducted three independent runs for the final divergence time estimates under the UCLN model with 20 million inferences and a sample frequency of 1000 steps. We used always the same parsimony tree as starting point. We compared the results and calculated pairwise Bayes factors for the difference in their marginal likelihoods. The first 4 million steps were cut off as burnin for each comparison. Low Bayes factors are a sign for high convergence of the values and compatibility of the inferences, while high Bayes factors indicate incompatibility.
Individual runs were combined with LogCombiner, TreeAnnotator and analyzed with Tracer v1.4 and FigTree v1.1.2 [114]. TreeAnnotator and LogCombiner are provided as part of the BEAST package.

\section{Additional material}

\begin{abstract}
Additional file $\mathbf{1}$ Incorporated sequences. GenBank accession numbers of all incorporated sequences are shown. Dotted lines indicate missing data. Percentage of overall missing base pairs per lineage are given (completeness). Sample origins of our analyzed individuals are coded with twoletter abbreviations according to the International Organization of Standardization: RU Russia, CU Cuba, CR Costa Rica, JM Jamaica, MX Mexico, p.e. GenBank sequences published earlier. Question marks (?) are used for samples with unknown origin. [*] Asterisks indicate sequences published within this paper and were submitted to EMBL-EBI database hosted by the European Molecular Biology Laboratory.

Additional file $\mathbf{2}$ Input file for the Bayesian analysis in BEAST (see methods section: Alignment 4). XML formatted input file for the Bayesian analysis in BEAST. Can be opened within a browser, or executed with the software BEAST.

Additional file 3 Concatenated alignment for the maximum-likelihood inference with RAxML (see methods section: Alignment 5).

Alignment file is in PHYLIP format and can be viewed with every text editor, or used directly in most phylogenetic software packages.
\end{abstract}

\section{Authors' contributions}

$\mathrm{OvH}$ was the initiator of this study. FM supervised the whole project, gave many ideas, helped to evaluate the results and to draw up the manuscript. TD made all the lab work, performed the phylogenetic analyses and wrote the manuscript.

\section{Acknowledgements}

We thank Marco Tschapka, Martina Nagy, Mirjam Knörnschild, and Ralph Simon for fruitful discussions and for providing tissue samples. Wolfram Schulze, Jana Ustinova, Dagmar Dachlauer, Andrea Ross, Claudius Kerth, Corinna Koch von Helversen, Sebastian Ebert, Heiko Stuckas, Kai Drilling, and Dirk Berger supported the study at different stages. We would like to thank Christian Voigt, Simon Ghanem, Markus Zweier, Inge Müller, Corine Schoebel, Ulrich Marckmann, Volker Runkel, Dina Dechmann, Kirsten Jung, Stefan Prost, Sebastian Lippold, Michael Knapp, and Maria Helbig for their willingness to discuss diverse aspects and giving advice. We thank the CBSU Web Computing Resources (BIOHPC) for their free web-based service for phylogenetic analysis with BEAST. Fruitful discussions occurred with Alexandros Stamatakis, Ignacio Gonzalo Bravo, and Olaf Bininda-Emonds during the Carolinensiel summer school in 2008. Finally we thank two anonymous reviewers for their excellent comments and help to improve this manuscript. The study was financed by the LuisePrell-Stiftung and the Schmauser-Stiftung at the University of Erlangen- Nürnberg.

\section{Author Details}

${ }^{1}$ Museum für Naturkunde, Leibniz Institute for Research on Evolution and Biodiversity at the Humboldt University Berlin, Invalidenstr. 43, 10115 Berlin, Germany, ${ }^{2}$ Department of Zoology, Animal Physiology, University of ErlangenNürnberg, Staudtstrasse 5, Erlangen, Germany and 3Senckenberg Natural History Collections Dresden, Museum of Zoology, Königsbrücker Landstrasse 159, 01109 Dresden, Germany

Received: 5 January 2010 Accepted: 4 June 2010 Published: 4 June 2010

\section{References}

1. Gardner AL: Chromosomal variation in Vampyressa and a review of chromosomal evolution in the Phyllostomidae (Chiroptera). Syst Zool 1977, 26:300-318

2. Findley JS: Bats: a community perspective Cambridge, Cambridge Univ Press; 1993. 
3. Gimenez EDA, Ferrarezzi H, Taddei VA: Lingual morphology and cladistic analysis of the New World nectar-feeding bats (Chiroptera: Phyllostomidae). J Comp Biol 1996, 1:41-64.

4. Freeman PW: Macroevolution in microchiroptera: recoupling morphology and ecology with phylogeny. Evol Ecol Res 2000, 2:317-335

5. Wetterer AL, Rockman MV, Simmons NB: Phylogeny of phyllostomid bats (Mammalia: Chiroptera): Data from diverse morphological systems, sex chromosomes, and restriction sites. Bull Amer Mus Nat Hist 2000, 248:1-200.

6. Giannini NP, Kalko KV: Trophic structure in a large assemblage of phyllostomid bats in Panama. Oikos 2004, 105:209-220.

7. Rex K, Kelm DH, Wiesner K, Matt FG, Kunz TH, Voigt CC: Species richness and structure of three Neotropical bat assemblages. Biol I Linn Soc 2008, 94:617-629.

8. Humphrey SR, Bonaccorso FJ, Zinn TL: Guild structure of surfacegleaning bats in Panama. Ecology 1983, 64:284-294

9. Dobat K, Peikert-Holle T: Blüten und Fledermäuse: Bestäubung durch Fledermäuse und Flughunde (Chiropterophilie) Frankfurt am Main, Germany: Waldemar Kramer; 1985.

10. Fleming $\mathrm{TH}$ : The short-tailed fruit bat: A study in plant-animal interactions Chicago Univ Press; 1988:1-380. [Wildlife Behavior and Ecology series].

11. Freeman PW: Frugivorous and animalivorous bats (Microchiroptera): Dental and cranial adaptations. Biol J Linn Soc 1988, 33:249-272.

12. Medellin RA: Prey of Chrotopterus auritus, with notes on feeding behavior. J Mammal 1988, 69:841-844.

13. Handley COJ, Wilson DE, Gardner AL: Demography and natural history of the common fruit bat, Artibeus jamaicensis, on Barro Colorado Island, Panama. Smithson Contrib Zool 1991, 511:1-173.

14. von Helversen O: Adaptations of flowers to the pollination by glossophagine bats. In Animal-plant interactions in tropical environments Edited by: Barthlott W, Naumann CM, Schuchmann SLK, Schuchmann KL. Bonn, Germany, Museum Koenig; 1993:41-59.

15. Freeman PW: Nectarivorous feeding mechanisms in bats. Biol $\mathrm{L}$ Linn Soc 1995, 56:439-463.

16. Proctor M, Yeo P, Lack A: The natural history of pollination Portland, Oregon, Timber Press; 1996.

17. Vogel $\mathrm{S}$ : Chiropterophilie in der neotropischen Flora. Neue Mitteilungen III. Flora, B 1969, 158:289-323.

18. Phillips CJ: The dentition of glossophagine bats: development, morphological characteristics, variation, pathology, and evolution. In Miscellaneous Publications of the Museum of Natural History Volume 54. University of Kansas; 1971:1-138.

19. Smith JD: Chiropteran evolution. In Biology of the Bats of New World Phyllostomidae. Part I Edited by: Baker RJ, Jones JK, Carter DC. Spec Publ Mus Tex Tech Univ; 1976:49-69.

20. Baker RJ, Bass RA: Evolutionary relationship of the Brachyphyllinae to the glossophagine genera Glossophaga and Monophyllus. J Mammal 1979, 60:364-372.

21. Hopkins HC: Floral biology and pollination ecology of the Neotropical species of Parkia. Ecology 1984, 72:1-23.

22. Eguiarte L, Búrquez A: Reproductive ecology of Manfreda brachystachya, an iteroparous species of Agavaceae. Southwest Nat 1987, 32:169-178.

23. Gribel R, Hay JD: Pollination ecology of Caryocar brasiliense (Caryocaraceae) in Central Brazil cerrado vegetation. J Trop Ecol 1993, 9:199-211.

24. von Helversen O: Blumenfledermäuse und Fledermausblumen Wechselbeziehungen zwischen Blüte und Bestäuber und energetische Grenzbedingungen. In Rundgespräche der Kommission für Ökologie. Band 10, Tropenforschung Bayr Akad Wiss; 1995:217-229.

25. Luckow M, Hopkins HCF: A cladistic analysis of Parkia (Leguminosae: Mimosoideae). Am J Bot 1995, 82:1300-1320.

26. Winter $Y$, Voigt CC, von Helversen $\mathrm{O}$ : Gas exchange during hovering flight in nectar-feeding bat Glossophaga soricina. J Exp Biol 1998, 201:237-244.

27. Dumont ER: The effect of food hardness on feeding behaviour in frugivorous bats (Phyllostomidae): an experimental study. J Zool 1999, 248:219-229.

28. Carstens BC, Lundrigan BL, Myers P: A Phylogeny of the Neotropical nectar-feeding bats (Chiroptera: Phyllostomidae) based on morphological and molecular data. J Mamm Evol 2002, 9:23-39.
29. von Helversen $O$, Winter $Y$ : Glossophagine bats and their flowers: costs and benefits for plants and pollinators. In Bat Ecology Volume 2003. 2nd edition. Edited by: Kunz TH, Fenton MB. Chicago and London, Chicago Univ Press :346-397.

30. Winter $Y$, von Helversen $\mathrm{O}$ : Operational tongue length in phyllostomid nectar-feeding bats. J Mammal 2003, 84:886-896.

31. Kelm DH, von Helversen $\mathrm{O}$ : How to budget metabolic energy - torpor in a small Neotropical mammal. J Comp Physiol B 2007, 177(6):667-677.

32. Voigt CC, Speakman JR: Nectar-feeding bats fuel their high metabolism directly with exogenous carbohydrates. Funct Ecol 2007, 21:913-921.

33. Griffiths TA: Systematics of the New World nectar-feeding bats (Mammalia: Phyllostomidae) based on the morphology of the hyoid and lingual regions. Am Mus Novit 1982, 27(42):1-45.

34. Heithaus ER, Stashko E, Anderson PK: Cumulative effects of plant- animal interactions on seed production by Bauhinia ungulata, a Neotropical legume. Ecology 1982, 63:1294-1302.

35. Winter $Y$ : Energetic cost of hovering flight in a nectar-feeding bat measured with fast-response respirometry. J Comp Physiol B 1998 168:434-444.

36. Norberg UM, Kunz TH, Steffensen JF, Winter Y, von Helversen O: The cost of hovering and forward flight in a nectar-feeding bat, Glossophaga soricina, estimated from aerodynamic theory. J Exp Biol 1993, 182:207-227.

37. Hedenström A, Johansson LC, Wolf M, Busse R, Winter Y, Spedding GR: Bat flight generates complex aerodynamic tracks. Science 2007 316(5826):894-897.

38. Howell D: Bats and pollen: physiological aspects of the syndrome of chiropterophily. Comp Biochem Physiol 1974, 48:263-276.

39. Stanley RG, Linskens HG: Pollen biology, biochemistry, management Berlin, Heidelberg, New York, Springer-Verlag; 1974.

40. Law BS: Physiological factors affecting pollen use by Queensland blossom bats, Syconycteris australis. Funct Ecol 1992, 65:634-648.

41. Fleming $T H$ : The use of stable isotopes to study the diets of plantvisiting bats. In Bats: Ecology, Behavior, and Evolution Edited by: Racey PA, McDonnell U, Swift S. Oxford, Oxford Univ Press; 1995:99-110.

42. Herrera LGM, del Río CM: Pollen digestion by New World Bats: Effects of processing time and feeding habits. Ecology 1998, 79:2828-2838.

43. Schondube JE, Herrera LGM, del Río CM: Diet and the evolution of digestion and renal function in phyllostomid bats. Zoology 2001, 104:59-73.

44. Mirón LLM, Herrera LGM, Ramírez PN, Hobson KA: Effect of diet quality on carbon and nitrogen turnover and isotopic discrimination in blood of a New World nectarivorous bat. J Exp Biol 2006, 209:541-548.

45. Simmons NB: Order Chiroptera. In Mammalian Species of the World: A Taxonomic and Geographic Reference 3rd edition. Edited by: Wilson DE, Reeder DM, Baltimore. Maryland: Johns Hopkins Univ Press; 2005:312-529.

46. Baker RJ, Hood CS, Honeycutt RL: Phylogenetic relationship and classification of the higher categories of the New World bat family Phyllostomidae. Syst Zool 1989, 38:228-238.

47. McKenna MC, Bell SK: Classification of mammals above the species level New York, NY, Columbia Univ Press; 1997.

48. Baker RJ, Hoofer SR, Porter CA, Van Den Bussche RA: Diversification among New World leaf-nosed bats: An evolutionary hypothesis and classification inferred from digenomic congruence of DNA sequence. Occ Pap Mus Tex Tech Univ 2003, 230:1-32.

49. Koopman KF: Chiroptera: Systematics. Handbook of Zoology, Vol 8, Part 60 Berlin, Germany: Walter de Gruyter; 1994

50. Jones KE, Purvis A, MacLarnon A, Bininda-Emonds ORP, Simmons NB: A phylogenetic supertree of the bats (Mammalia: Chiroptera). Biol Rev 2002, 77:223-259.

51. Drummond AJ, Ho SYW, Rawlence N, Rambaut A: A rough guide to BEAST 1.42007.

52. Miller GSJ: The families and genera of bats. Bull US Nat Mus 1907, 57:1-282.

53. Simpson GG: The principles of classification and a classification of the mammals. Bull Am Mus Nat Hist 1945, 85:1-350.

54. de la Torre L: The evolution, variation, and systematics of the Neotropical bats of the genus Sturnira. In PhD thesis Univ Illinois, Urbana; 1961

55. Silva-Taboda GS, Pine RH: Morphological and behavioral evidence for the relationship between the bats genus Brachyphylla and the Phylonycterinae. Biotropica 1969, 1:10-19. 
56. Koopman KF, Jones JKJ: A classification of bats. In About Bats Edited by: Slaughter BH, Walton WD, Dallas, TX. South Meth Univ Press; 1970:22-28.

57. Corbet GB, Hill JE: A world list of mammalian species 1st edition. London: British Museum; 1980

58. Baker RJ, Honeycutt RL, Arnold ML, Sarich VM, Genoways AA: Electrophoretic and immunological studies of the relationship of the Brachyphyllinae and the Glossophaginae. J Mammal 1981, 62:665-672.

59. Baker RJ, Porter CA, Patton JC, Van Den Bussche RA: Systematics of the family Phyllostomidae based on RAG2 DNA sequences. Occ Pap Mus Tex Tech Univ 2000, 202:1-16.

60. Rex K, Czaczkes BI, Michener R, Kunz TH, Voigt CC: Specialization and omnivory in diverse mammalian assemblages. Ecoscience 2010, 17(1):37-46.

61. Norberg UM, Fenton MB: Carnivorous bats? Biol J Linn Soc 1988, 33:383-394.

62. Barclay RMR, Fenton MB, Tuttle MD, Ryan MJ: Echolocation calls produced by Trachops cirrhosus while hunting frogs. Can J Zool 1981, 59:750-753.

63. Tuttle MD, Ryan MJ: Bat predation and the evolution of frog vocalizations in the Neotropics. Science 1981, 214:677-678.

64. Ibáñez C, Juste J, García-Mudarra JL, Agirre-Mendi PT: Bat predation on nocturnally migrating birds. PNAS 2001, 98:9700-9702.

65. Popa-Lisseanu AG, Delgado-Huertas A, Forero MG, Rodríguez A, Arlettaz R, Ibáñez C: Bats' conquest of a formidable foraging niche: The myriads of nocturnally migrating songbirds. PLOS ONE 2007, 2(2):e205.

66. Cloutier D, Thomas DW: Carollia perspicillata. Mammal species 1992, 417:1-9.

67. Haiduk MW, Baker RJ: Scientific method, opinion, phylogenetic reconstruction and nectar- feeding bats: A response to Griffiths and Warner. Syst Zool 1984, 33:343-350.

68. Smith JD, Hood CS: Genealogy of the New World nectar-feeding bats revisited: a reply to Griffiths. Syst Zool 1984, 33:435-460.

69. Jones KE, Bininda-Emonds ORP, Gittleman JL: Bats, clocks, and rocks: Diversification patterns in Chiroptera. Evolution 2005, 59(10):2243-2255.

70. Allmon WD, Bottjer DJ: Evolutionary Paleoecology: The Ecological Context of Macroevolutionary Change New York, Columbia Univ Press; 2001.

71. Rogers RD, Karason H, Van Der Hilst RD: Epeirogenic uplift above a detached slab in northern Central America. Geology 2002, 30(11):1031-1034

72. MacFadden BJ, Higgins P: Ancient ecology of 15-million-year-old browsing mammals within C3 plant communities from Panama. Oecologia 2004, 140:169-182.

73. MacMillan I, Gans PB, Alvarado G: Middle Miocene to present plate tectonic history of the southern Central American Volcanic Arc. Tectonophysics 2004, 392(1-4):325-348.

74. Kirby MX, Jones DS, MacFadden BJ: Lower Miocene stratigraphy along the Panama Canal and its bearing on the Central American peninsula. PloS ONE 2008, 3(7):e2791

75. Meschede M, Barckhausen U, Engels M, Weinrebe W: The trace of the Pacific-Cocos-Nazca triple junction in the Central Pacific and the formation of an overlapping spreading centre. Terra Nova 2008, 20(3):246-251.

76. Shevenell AE, Kennett JP, Lea DW: Middle Miocene southern ocean cooling and Antarctic cryosphere expansion. Science 2004, 17:1766-1770.

77. Singh VP, Harmon RS: The Río Chagres, Panama: A multidisciplinary profile of a Tropical watershed. In Water Science and Technology Library Netherlands: Springer; 2005:45-62.

78. Kürschner WM, Kvacek Z, Dilcher DL: The impact of Miocene atmospheric carbon dioxide fluctuations on climate and the evolution of terrestrial ecosystems. PNAS 2008, 105(2):449-453.

79. Coyne JA, Orr HA: Speciation Sunderland, Massachusetts USA, Sinauer Associates, Inc; 2004.

80. Bleiweiss R: Tempo and mode of hummingbird evolution. Biol J Linn SoC 2008, 65:63-76.

81. Porter CA, Goodman M, Stanhope MJ: Evidence on mammalian phylogeny from sequences of exon 28 of the von Willebrand factor gene. Mol Phylogenet Evol 1996, 5:89-101.

82. Teeling CE, Scally M, Kao DJ, Romagnoli ML, Springer MS, Stanhope MJ: Molecular evidence regarding the origin of echolocation and flight in bats. Nature 2000, 403(13):188-192.
83. Murphy WJ, Eizirik E, Johnson WE, Zhang JP, Ryder OA, OBrien SJ: Molecular phylogenetics and the origins of placental mammals. Nature 2001, 409:614-618.

84. Piaggio AJ, Perkins SL: Molecular phylogeny of North American longeared bats (Vespertilionidae: Corynorhinus); inter- and intraspecific relationships inferred from mitochondrial and nuclear DNA sequences. Mol Phylogenet Evol 2005, 37(3):762-775.

85. Mayer F, von Helversen O: Cryptic diversity in European bats. Proc R Soc Lond 2001, 268B:1825-1832.

86. SEQUENCHER 4.7 DNA sequence assembly software: Gene Codes Corporation [http://www.genecodes.com/]

87. Thompson JD, Higgins DG, Gibson TJ: CLUSTAL W: improving the sensitivity of progressive multiple sequence alignment through sequence weighting, positions-specific gap penalties and weight matrix choice. Nucl Acids Res 1994, 22:4673-4680.

88. Hall TA: BioEdit: a user-friendly biological sequence alignment editor and analysis program for Windows 95/98/NT. Nucl Acids Symp Ser 1999, 41:95-98.

89. PAUP*: Phylogenetic Analysis Using Parsimony (and other methods) 4.0 Beta [http://www.sinauer.com/detail.php?id=8060]

90. Abascal F, Zardoya R, Posada D: ProtTest: Selection of best-fit models of protein evolution. Bioinformatics 2005, 21(9):2104-2105.

91. Yang Z: Synonymous and nonsynonymous rate variation in nuclear genes of mammals. Mol Evol 1998, 46:409-418.

92. Posada D: jModelTest: Phylogenetic model averaging. Mol Biol Evol 2008, 25(7):1253-1256.

93. Rodriguez F, Oliver JF, Marin A, Medina JR: The general stochastic model of nucleotide substitutions. J Theor Biol 1990, 142:485-501.

94. Akaike $\mathrm{H}$ : A new look at the statistical model identification. IEEE Trans Aut Cont 1974, 19(6):716-723.

95. Schwarz GE: Estimating the dimension of a model. Ann Stat 1978, 6(2):461-464

96. Zharkikh A: Estimation of evolutionary distances between nucleotide sequences. J Mol Evol 1994, 39:315-329.

97. McGuire JA, Witt CC, Altshuler DL, Remsen JV: Phylogenetic systematics and biogeography of hummingbirds: Bayesian and maximum likelihood analyses of partitioned data and selection of an appropriate partitioning strategy. Syst Bio/ 2007, 56:837-856.

98. Stamatakis A, Ludwig T, Meier H: A program for sequential, parallel distributed inference of large phylogenetic trees. Concurrency and Computation: Pract Exper 2005, 17(14):1705-1723.

99. Stamatakis A: RAxML-VI-HPC: Maximum likelihood-based phylogenetic analyses with thousands of taxa and mixed models. Bioinformatics 2006, 22(21):2688-2690.

100. Stamatakis A, Hoover P, Rougemont J: A rapid bootstrap algorithm for the RAxML web servers. Syst Bio/ 2008, 57:758-771.

101. Stamatakis A, Ludwig T, Meier H: RAxML-III: a fast program for maximum likelihood-based inference of large phylogenetic trees. Bioinformatics 2005, 21(4):456-463.

102. Stamatakis A, Ott M, Ludwig T: RAxML-OMP: An efficient program for phylogenetic inference on SMPs. Proceedings of 8 th International Conference on Parallel Computing Technologies (PaCT2005) 2005, 3606:288-302.

103. Maddison WP, Maddison DR: Mesquite: a modular system for evolutionary analysis 2009

104. Cunningham CW, Omland KE, Oakley TH: Reconstructing ancestral character states: A critical reappraisal. Tree 1998, 13(9):361-366.

105. Lewis PO: A likelihood approach to estimating phylogeny from discrete morphological character data. Syst Bio/ 2001, 50:913-925.

106. Drummond AJ, Rambaut A: BEAST: Bayesian evolutionary analysis by sampling trees. BMC Evol Biol 2007, 7:214.

107. Hasegawa M, Kishino $H$, Yano T: Dating of the human-ape splitting by a molecular clock of mitochondrial DNA. Mol Evol 1985, 22:160-174.

108. Morgan GS: New bats in the Neotropical families Emballonuridae and Mormoopidae from the Oligocene and Miocene of Florida, and the biochronology of Florida Whitneyan, Arikareean, and Hemingfordian faunas. J Vert Paleont 2002, 22(Suppl 3):90A.

109. Czaplewski NJ, Takai M, Naeher TM, Shigehara N, Setoguchi T: Additional bats from the Middle Miocene La Venta fauna of Colombia. Rev Acad Colombiana de Cienc Exactas, Fis Nat 2003, 27:263-282 
110. Czaplewski NJ, Morgan GS, McLeod SA: Evolution of Tertiary mammals of North America, Vol 2, small mammals, Xenarthrans, and marine mammals Cambridge, Cambridge Univ Press; 2008.

111. Drummond AJ, Nicholls GK, Rodrigo AG, Solomon W: Estimating mutation parameters, population history and genealogy simultaneously from temporally spaced sequence data. Genetics 2002, 161:1307-1320

112. Drummond AJ, Ho SYW, Phillips MJ, Rambaut A: Relaxed phylogenetics and dating with confidence. PLoS Biology 2006, 4(5):e88.

113. Molecular evolution, phylogenetics and epidemiology [http:// tree.bio.ed.ac.uk/software/tracer/]

114. Molecular evolution, phylogenetics and epidemiology [http:// tree.bio.ed.ac.uk/software/figtree//

115. Ferrarezzi H, Gimenez EDA: Systematic patterns and the evolution of feeding habits in Chiroptera (Archonta: Mammalia). J Comp Biol 1996, 1:75-94

116. Dumont ER: Feeding mechanisms in bats: Variation within the constraints of flight. Integr Comp Biol 2007, 47:137-146.

117. The Sorenson lab Boston University [http://people.bu.edu/msoren/ TreeRot.html]

118. Pons J, Barraclough TG, Gomez-Zurita J, Cardoso A, Duran DP, Hazell S, Kamoun S, Sumlin WD, Vogler AP: Sequence-based species delimitation for the DNA taxonomy of undescribed insects. Syst Bio/ 2006, 55:595-609.

119. Fontaneto DE, Herniou C, Boschetti M, Caprioli G, Melone C, Ricci C, Barraclough TG: Independently evolving species in asexual bdelloid rotifers. PLoS Biology 2007, 5:e87.

120. Monaghan MT, Wild R, Elliot M, Fujisawa T, Balke M, Inward DJG, Lees DC, Ranaivosolo R, Eggleton P, Barraclough TG, Vogler AP: Accelerated species inventory on Madagascar using coalescent-based models of species delineation. Syst Biol 2009, 58(3):298-311.

doi: 10.1186/1471-2148-10-165

Cite this article as: Datzmann et al., Evolution of nectarivory in phyllostomid bats (Phyllostomidae Gray, 1825, Chiroptera: Mammalia) BMC Evolutionary Biology 2010, 10:165

\section{Submit your next manuscript to BioMed Central} and take full advantage of:

- Convenient online submission

- Thorough peer review

- No space constraints or color figure charges

- Immediate publication on acceptance

- Inclusion in PubMed, CAS, Scopus and Google Scholar

- Research which is freely available for redistribution

Submit your manuscript at www.biomedcentral.com/submit
C Biomed Central 